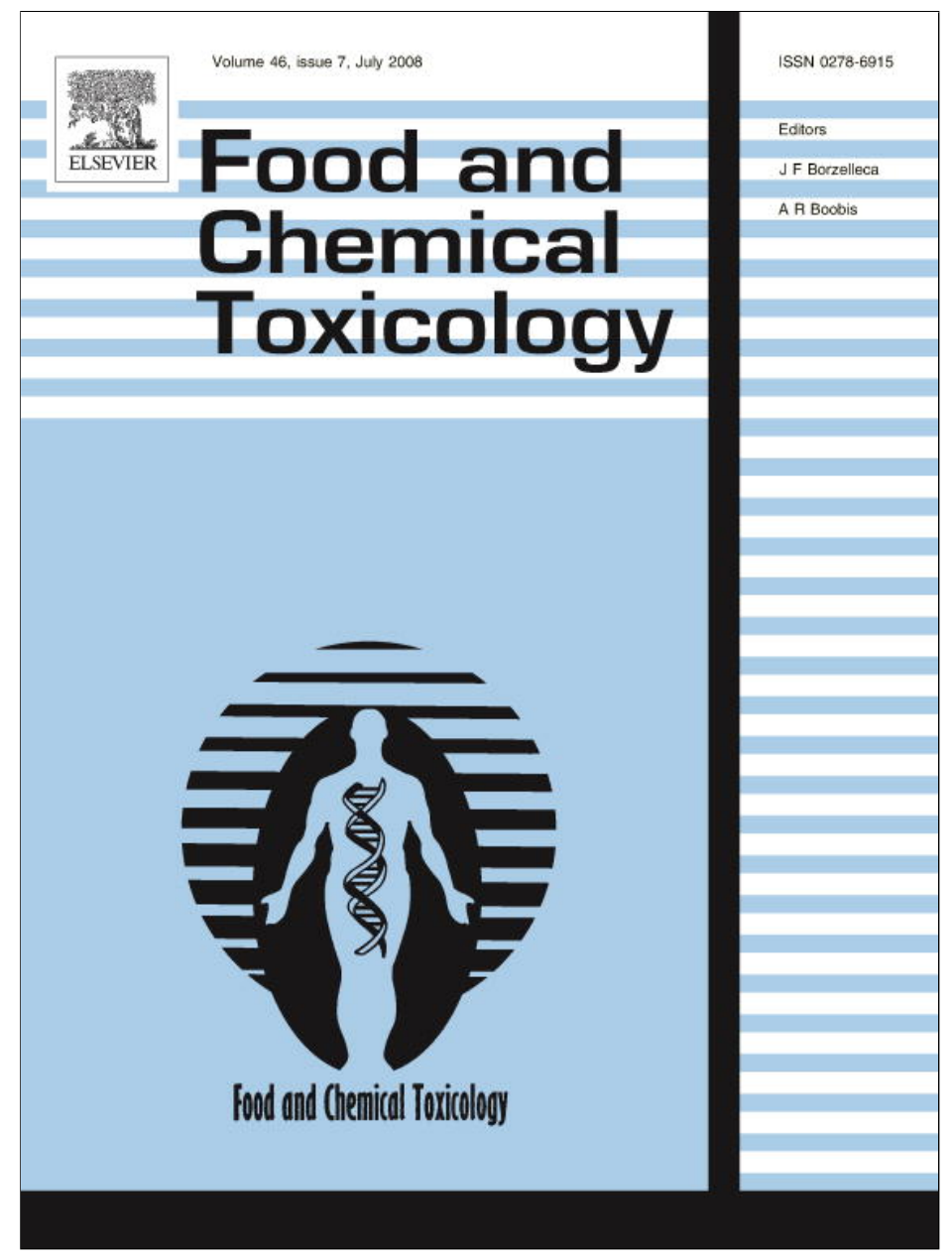

This article appeared in a journal published by Elsevier. The attached copy is furnished to the author for internal non-commercial research and education use, including for instruction at the authors institution and sharing with colleagues.

Other uses, including reproduction and distribution, or selling or licensing copies, or posting to personal, institutional or third party websites are prohibited.

In most cases authors are permitted to post their version of the article (e.g. in Word or Tex form) to their personal website or institutional repository. Authors requiring further information regarding Elsevier's archiving and manuscript policies are encouraged to visit: 


\title{
Total phenols, antioxidant potential and antimicrobial activity of walnut (Juglans regia L.) green husks
}

\author{
Ivo Oliveira, Anabela Sousa, Isabel C.F.R. Ferreira, Albino Bento, Letícia Estevinho, José Alberto Pereira* \\ CIMO/Escola Superior Agrária, Instituto Politécnico de Bragança, Campus Sta Apolónia, Apartado 1 172, 5301-855 Bragança, Portugal
}

\section{A R T I C L E I N F O}

\section{Article history:}

Received 4 February 2008

Accepted 11 March 2008

\section{Keywords:}

Walnut green husks

Total phenols

Antimicrobial activity

Antioxidant activity

\begin{abstract}
A B S T R A C T
The total phenols content and antioxidant and antimicrobial activities were studied in walnut (Juglans regia $\mathrm{L}$.) green husks aqueous extracts of five different cultivars (Franquette, Mayette, Marbot, Mellanaise and Parisienne). Total phenols content was determined by colorimetric assay and their amount ranged from $32.61 \mathrm{mg} / \mathrm{g}$ of GAE ( $c v$. Mellanaise) to $74.08 \mathrm{mg} / \mathrm{g}$ of GAE t ( $c v$. Franquette). The antioxidant capacity of aqueous extracts was assessed through reducing power assay, scavenging effects on DPPH (2,2-diphenyl-1-picrylhydrazyl) radicals and $\beta$-carotene linoleate model system. A concentration-dependent antioxidative capacity was verified in reducing power and DPPH assays, with $\mathrm{EC}_{50}$ values lower than $1 \mathrm{mg} /$ $\mathrm{mL}$ for all the tested extracts. The antimicrobial capacity was screened against Gram positive and Gram negative bacteria, and fungi. All the extracts inhibited the growth of Gram positive bacteria, being Staphylococcus aureus the most susceptible one with MIC of $0.1 \mathrm{mg} / \mathrm{mL}$ for all the extracts. The results obtained indicate that walnut green husks may become important in the obtainment of a noticeable source of compounds with health protective potential and antimicrobial activity.
\end{abstract}

(C) 2008 Elsevier Ltd. All rights reserved.

\section{Introduction}

Walnut (Juglans regia L.) is a valuable crop being the nut very popular and largely consumed. In Portugal, this species is widely spread throughout the country. Not only dry fruit (nuts) are used but also green walnuts, shells, kernels, bark, green walnut husks (epicarp) and leaves have been used in both cosmetic and pharmaceutical industry (Stampar et al., 2006).

In recent decades an increasing tendency towards the use of natural substances instead of the synthetic ones has been observed. As the synthetic materials and products are more complex in comparison to natural substances, it will take a long time for them to complete their natural cycles and return to nature; thus causing a lot of environmental pollution. Also with the increase in the price of raw materials, the problem of cost benefits for chemical production is becoming more considerable. Natural antioxidants, such as phenolic compounds, used as natural antioxidants, are gaining importance, due to their benefits for human health, decreasing the risk of degenerative diseases by reduction of oxidative stress and inhibition of macromolecular oxidation (Silva et al., 2004; Pulido et al., 2000; Tseng et al., 1997). Their use as preserving food additives (Zupko et al., 2001) had increasing interest.

\footnotetext{
* Corresponding author. Tel.: +351 273 303277; fax: +351 273325405

E-mail address: jpereira@ipb.pt (J.A. Pereira).
}

In addition to antioxidant activity, several studies demonstrated the antimicrobial activity of phenols and/or phenolic extracts (Fernández et al., 1996; Hoult and Payá, 1996; Pereira et al., 2006, 2007a,b; Proestos et al., 2005; Puupponen-Pimiä et al., 2001; Rauha et al., 2000; Sousa et al., 2006; Zhu et al., 2004), making them a good alternative to antibiotics and chemical preservatives. There is an extended interest in using natural antimicrobial compounds, as the consumer's pressure on the food industry augments, to avoid chemical preservatives and due to the increasing resistance to antibiotics (Oliveira et al., 2007; Cowan, 1999).

Walnut's green husk is a by-product of the walnut production, having scarce use. Thus, using husk as a source of phytochemicals will increase the value of the walnut production, as well as offer utilization for a by-product, which is produced in a large quantity.

Different works demonstrated the potential antioxidant of walnut products, especially fruits (Espín et al., 2000; Li et al., 2006, 2007; Pereira et al., 2008) but also leaves (Pereira et al., 2007b) and liqueurs produced by green fruits (Stampar et al., 2006). Studies have also demonstrated the antimicrobial activity of walnut products, particularly of bark (Alkhawajah, 1997), leaves (Clark et al., 1990; Pereira et al., 2007b), fruits (Pereira et al., 2008) and the specific compound juglone (Clark et al., 1990) but until this time the information about walnut green husks is almost inexistent.

In the present work, green husk (Fig. 1) from five walnut cultivars ( $c v$. Franquette, Marbot, Mayette, Mellanaise and Parisienne) grown in Portugal, were studied, regarding their total phenols content, antioxidant and antimicrobial activities. Antioxidant potential 


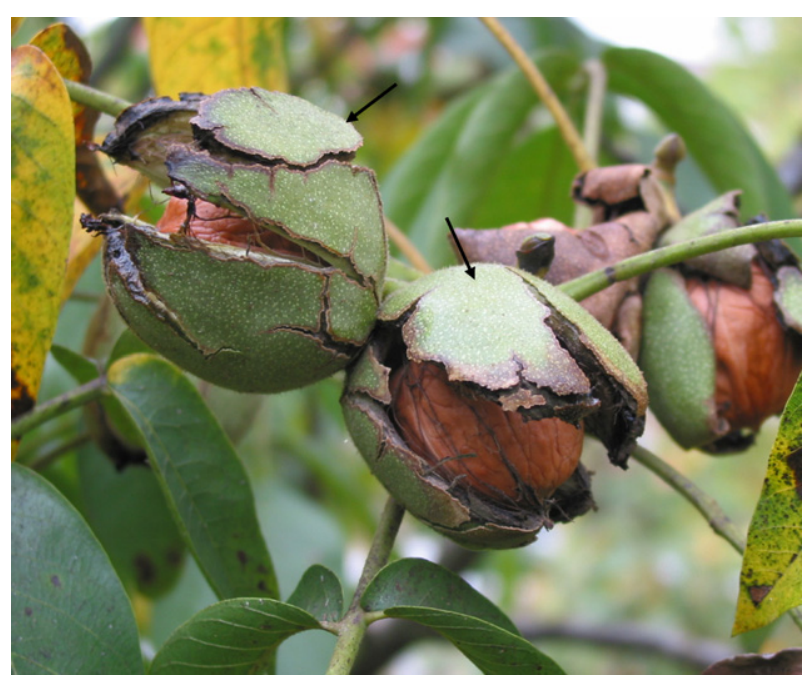

Fig. 1. Walnut green husks.

was accessed by the reducing power assay, the scavenging effect on DPPH (2,2-diphenyl-1-picrylhydrazyl) radicals and $\beta$-carotene linoleate model system. Antimicrobial capacity was also accessed, against Gram positive (Bacillus cereus, B. subtilis, Staphylococcus aureus) and Gram negative bacteria (Pseudomonas aeruginosa, Escherichia coli, Klebsiella pneumoniae) and fungi (Candida albicans, Cryptococcus neoformans).

\section{Materials and methods}

\subsection{Samples}

Walnuts' green husks were obtained from five J. regia L. cultivars: Franquette, Marbot, Mayette, Mellanaise and Parisienne that were collected on October 2006 in Bragança, northeast of Portugal (41 $47^{\prime} 47.50918^{\prime \prime} \mathrm{N}, 6^{\circ} 46^{\prime} 5.71990$ " W, $744.341 \mathrm{~m}$ ). The orchard has a planting density of $3.5 \times 7 \mathrm{~m}$. The trees are ten years old, being pruned when necessary. No phytosanitary treatments were applied. Per cultivar, approximately $2 \mathrm{~kg}$ of fruits were handpicked from the soil, and the walnut green husks were removed, put in plastic bags and immediately frozen at $-20^{\circ}$. The plant material was then freeze dried.

\subsection{Samples preparation}

Before each kind of analysis (total phenols determination, antioxidant and antimicrobial activities assays) the walnuts' green husk were extracted with $250 \mathrm{~mL}$ of boiling water for $45 \mathrm{~min}$, and filtered through Whatman no. 4 paper (for each cultivar, three powdered subsamples, $5 \mathrm{~g}, 20$ mesh). The aqueous extracts were frozen, lyophilized and redissolved in water at concentrations of $100 \mathrm{mg} / \mathrm{mL}$ and $10 \mathrm{mg} / \mathrm{mL}$ for antimicrobial and antioxidant activities assays, respectively.

\subsection{Determination of total phenols content}

Total phenols content in the obtained extracts were estimated by a colorimetric assay based on procedures described by Singleton and Rossi (1965) with some modifications. Briefly, $1 \mathrm{~mL}$ of sample was mixed with $1 \mathrm{~mL}$ of Folin and Ciocalteu's phenol reagent. After $3 \mathrm{~min}, 1 \mathrm{~mL}$ of saturated sodium carbonate solution was added to the mixture and adjusted to $10 \mathrm{~mL}$ with distilled water. The reaction was kept in the dark for $90 \mathrm{~min}$, after which the absorbance was read at $725 \mathrm{~nm}$ (Analytik Jena 2002004 spectrophotometer). Gallic acid was used for constructing the standard curve (0.01-0.4 mM). The results are expressed as $\mathrm{mg}$ of gallic acid equivalents/g of extract (GAEs)

\subsection{Antioxidant Activity}

\subsubsection{Reagents}

BHA (2-tert-butyl-4-methoxyphenol), TBHQ (tert-butylhydroquinone) and $\alpha$ tocopherol were purchased from Sigma (St. Louis, MO, USA). 2,2-Diphenyl-1-picrylhydrazyl (DPPH) was obtained from Alfa Aesar. All other chemicals were obtained from Sigma Chemical Co. (St. Louis, USA). Methanol was obtained from Pronalab (Lisboa, Portugal). Water was treated in a Mili-Q water purification system (TGI Pure Water Systems, USA).

\subsubsection{Reducing power assay}

The reducing power was determined according to a described procedure (Oyaizu, 1986; Ferreira et al., 2007). Various concentrations of sample extracts ( $2.5 \mathrm{~mL})$ were mixed with $2.5 \mathrm{~mL}$ of $200 \mathrm{mmol} / \mathrm{L}$ sodium phosphate buffer $(\mathrm{pH} \mathrm{6.6)}$ and $2.5 \mathrm{~mL}$ of $1 \%$ potassium ferricyanide. The mixture was incubated at $50{ }^{\circ} \mathrm{C}$ for $20 \mathrm{~min}$. After incubation $2.5 \mathrm{~mL}$ of $10 \%$ tricloroacetic acid $(\mathrm{w} / \mathrm{v})$ were added and then the mixture was centrifuged at $1000 \mathrm{rpm}$ in a refrigerated centrifuge (Centorion K24OR- 2003), for $8 \mathrm{~min}$. The upper layer $(5 \mathrm{~mL})$ was mixed with $5 \mathrm{~mL}$ of deionised water and $1 \mathrm{~mL}$ of $0.1 \%$ of ferric chloride, and the absorbance was measured spectrophotometrically at $700 \mathrm{~nm}$. The extract concentration providing 0.5 of absorbance $\left(\mathrm{EC}_{50}\right)$ was calculated from the graph of absorbance registered at $700 \mathrm{~nm}$ against the correspondent extract concentration. BHA and $\alpha$-tocopherol were used as reference compounds.

\subsubsection{Scavenging effect assay}

The capacity to scavenge the 2,2-diphenyl-1-picrylhydrazyl (DPPH) free radical was monitored according to a method reported before (Hatano et al., 1988). Various concentrations of sample extracts $(0.3 \mathrm{~mL})$ were mixed with $2.7 \mathrm{~mL}$ of methanolic solution containing DPPH radicals $\left(6 \times 10^{-5} \mathrm{~mol} / \mathrm{L}\right)$. The mixture was shaken vigorously and left to stand in the dark until stable absorption values were obtained. The reduction of the DPPH radical was measured by monitoring continuously the decrease of absorption at $517 \mathrm{~nm}$. DPPH scavenging effect was calculated as percentage of DPPH discolouration using the equation: \% scavenging effect $=\left[\left(A_{\mathrm{DPPH}}-A_{\mathrm{S}}\right)\right]$ $\left.A_{\mathrm{DPPH}}\right] \times 100$, where $A_{\mathrm{S}}$ is the absorbance of the solution when the sample extract has been added at a particular level and $A_{\mathrm{DPPH}}$ is the absorbance of the DPPH solution. The extract concentration providing $25 \%$ inhibition $\left(\mathrm{EC}_{25}\right)$ was calculated from the graph of scavenging effect percentage against extract concentration. BHA and $\alpha-$ tocopherol were used as reference compounds.

\subsection{4. $\beta$-Carotene linoleate model system}

The antioxidant activity of walnut leaf extracts was evaluated according to a described procedure (Mi-Yae et al., 2003) $\beta$-carotene solution was prepared by dissolving $2 \mathrm{mg}$ of $\beta$-carotene in $10 \mathrm{~mL}$ of chloroform. Two millilitres of this solution were placed in a $100 \mathrm{~mL}$ round-bottom flask. After chloroform removal, at $40{ }^{\circ} \mathrm{C}$ under vacuum, $40 \mathrm{mg}$ of linoleic acid, $400 \mathrm{mg}$ of Tween 80 emulsifier, and $100 \mathrm{~mL}$ of distilled water were added to the flask under vigorous shaking. Aliquots $(4.8 \mathrm{~mL})$ of this emulsion were transferred into different test tubes containing $0.2 \mathrm{~mL}$ of different concentrations of walnut leaf extracts. The tubes were shaken and incubated at $50^{\circ} \mathrm{C}$ in a water bath. As soon as the emulsion was added to each tube, the zero time absorbance at $470 \mathrm{~nm}$ was measured. Absorbance readings were then recorded until the control sample had changed colour. A blank assay, devoid of $\beta$-carotene, was prepared for background subtraction. Antioxidant activity was calculated using the following equation: Antioxidant activity $=(\beta$-carotene content after $2 \mathrm{~h}$ of assay/initial $\beta$-carotene content $) \times 100$. The assays were carried out in triplicate and the results were expressed as mean values \pm standard deviations. The extract concentration providing $50 \%$ antioxidant activity $\left(\mathrm{EC}_{50}\right)$ was calculated from the graph of antioxidant percentage against extract concentration. TBHQ was used as reference compound.

\subsection{Antimicrobial activity}

\subsubsection{Reagents}

Ampicillin and cycloheximide were of the highest available quality, and purchased from Merck (Darmstadt, Germany). Water was treated in a Mili-Q water purification system (TGI Pure Water Systems, USA).

\subsubsection{Microorganisms and culture conditions}

Microorganisms CECT were obtained from the Spanish type culture collection (CECT) of Valencia University, while microorganisms ESA were clinically isolated strains identified in Microbiology Laboratory of Escola Superior Agrária de Bragança. Gram + (Bacillus cereus CECT 148, B. subtilis CECT 498 and Staphylococus aureus ESA 7 isolated from pus) and Gram - (Escherichia coli CECT 101, Pseudomonas aeruginosa CECT 108 and Klebsiella pneumoniae ESA 8 isolated from urine) bacteria, and fungi (Candida albicans CECT 1394 and Cryptococcus neoformans ESA 3 isolated from vaginal fluid) were used to screen antimicrobial activity of the three walnut cultivars. Microorganisms were cultured aerobically at $37^{\circ} \mathrm{C}$ (Scientific 222 oven model, 2003 ) in nutrient agar medium for bacteria, and at $30^{\circ} \mathrm{C}$ (Scientific 222 oven model, 2003 ) in sabouraud dextrose agar medium for fungi.

\subsubsection{Test assays for antimicrobial activity}

The screening of antibacterial activities against Gram + and Gram - bacteria and fungi and the determination of the minimal inhibitory concentration (MIC) were achieved by an adaptation of the agar streak dilution method based on radial diffu- 
sion (Ferreira et al., 2004; Sousa et al., 2006). Suspensions of the microorganism were prepared to contain approximately $10^{8} \mathrm{cfu} / \mathrm{mL}$, and the plates containing aga medium were inoculated ( $100 \mu \mathrm{L}$; spread on the surface). Each sample $(50 \mu \mathrm{L})$ was placed in a hole ( $3 \mathrm{~mm}$ depth, $4 \mathrm{~mm}$ diameter) made in the centre of the agar. Under the same conditions, different solutions of ampicillin (antibacterial) and cycloheximide (antifungal) were used as standards. The MIC was considered to be the lowest concentration of the tested sample able to inhibit the growth of bacteria after $24 \mathrm{~h}$ and fungi after $48 \mathrm{~h}$. The diameters of the inhibition zones corresponding to the MICs were measured using a ruler, with an accuracy of $0.5 \mathrm{~mm}$. Each inhibition zone diameter was measured three times (three different plates) and the average was considered. A control using only inoculation was also carried out.

\section{Results and discussion}

\subsection{Total phenols content}

The total phenols content in walnut green husks aqueous extracts was different according to the variety. $c v$. Franquette showed the high amount of these compounds, with $74.08 \mathrm{mg} / \mathrm{g}$ of GAE, being 1.7-2.3-fold higher than for other varieties. The lowest amounts were obtained for Mellanaise aqueous extracts with $32.61 \mathrm{mg} / \mathrm{g}$ of GAE (Table 1 ). The extraction yields were very similar in the different walnut varieties ranging from 31.63 and $33.69 \%$.

A few studies were developed concerning the phenolic composition of green walnut husks. Juglone (5-hydroxy-1,4-naphthoquinone) is known as a characteristic compound of Juglans spp. being reported its occurrence in green walnut husks (Mahoney et al., 2000). These authors report also the existence of other naphtoquinones. On the other hand, Stampar et al. (2006) identified thirteen phenolic compounds in walnut husks: chlorogenic acid, caffeic acid, ferulic acid, sinapic acid, gallic acid, ellagic acid, protocatechuic acid, syringic acid, vanillic acid, catechin, epicatechin, myricetin, and juglone. However, in the study developed by Stampar et al. (2006) they collected walnuts with green husk just before the hardening of the endocarp, and probably this fact could interfere in the identified compounds. Recently, Pereira et al. (2007b) reported, in walnut leaves, the identification and quantification of ten phenolic compounds, namely 3- and 5-caffeoylquinic acids, 3- and 4-p-coumaroylquinic acids, $p$-coumaric acid, quercetin 3-galactoside, quercetin 3-pentoside derivative, quercetin 3-arabinoside, quercetin 3-xyloside and quercetin 3-rhamnoside. In those matrices the main constituent was found to be quercetin 3-galactoside (Amaral et al., 2004; Pereira et al., 2007b).

\subsection{Antioxidant activity}

In this study, the antioxidant capacity against ROS species of walnut green husk samples was accessed by three different assays: reducing power, scavenging activity on DPPH radicals and lipid peroxidation inhibition by $\beta$-carotene-linoleate system. ROS occurs in foods and are mainly responsible for the initiation of oxidation reaction. ROS react with lipids, proteins, sugars and vitamins, producing undesirable volatile compounds, destroying essential fatty acids, amino acids and vitamins and producing carcinogens (Almeida et al., 2008), and make food products less acceptable or

Table 1

Extraction yield (in percentage) and total phenols content (mg GAEs/g) aqueous extracts of walnut green husks from the Franquette, Mayette, Marbot, Mellanaise and Parisienne cultivars

\begin{tabular}{lll}
\hline Cultivar & Extraction yield $(\%)$ & Total phenols contents \\
\hline Franquette & $31.63 \pm 0.98$ & $74.08 \pm 0.02$ \\
Marbot & $33.30 \pm 3.33$ & $43.77 \pm 0.01$ \\
Mayette & $32.19 \pm 1.46$ & $41.45 \pm 0.01$ \\
Mellanaise & $32.41 \pm 3.75$ & $32.61 \pm 0.01$ \\
Parisienne & $33.69 \pm 1.24$ & $38.76 \pm 0.01$ \\
\hline
\end{tabular}

unacceptable to consumers. In biological systems, oxidative stress, resulting from an imbalance between the generation of ROS and the antioxidant defence capacity of the cell affects major cellular components, including lipids, proteins and DNA. Continuous overproduction of ROS and/or the decrease in antioxidant defences may contribute to the development of several hearth diseases (Valko et al., 2007).

Green walnut husks extracts revealed a strong reducing power. The reducing power of a compound may serve as a significant indicator of its potential antioxidant activity (Meir et al., 1995). The presence of reducers (i.e. antioxidants) causes the reduction of the $\mathrm{Fe}^{3+} /$ ferricyanide complex to the ferrous form $\left(\mathrm{Fe}^{2+}\right)$ monitored at $700 \mathrm{~nm}$ (Sousa et al., 2008). In this assay, the yellow colour of the test solution changes to green depending on the reducing power of the test specimen. All the aqueous walnut husks extracts presented a concentration-dependent activity (Fig. 2) increasing the absorbance at $700 \mathrm{~nm}$ with increasing concentration. At a very low extract concentrations $(0.1 \mathrm{mg} / \mathrm{mL})$ the absorbance at $700 \mathrm{~nm}$ varied from 0.09 ( $c v$. Mellanaise) and 0.18 ( $c v$. Franquette). To obtain similar absorbance values with the tested standards we need to increase 36 -fold for BHA (abs at $700=0.12$ at $3.6 \mathrm{mg} / \mathrm{mL}$ ) and 86 -fold for $\alpha$-tocopherol (abs at $700=0.13$ at $8.6 \mathrm{mg} / \mathrm{mL}$ ). For extract concentrations of $1 \mathrm{mg} / \mathrm{mL}$ the reducing power values varied from 1.01 ( $c v$. Mellanaise) to 2.00 ( $c v$. Franquette) (Fig. 2). $\mathrm{EC}_{50}$ values obtained for aqueous walnut husks extracts were lower than $1.8 \mathrm{mg} / \mathrm{mL}$. In general, extracts with high total phenols content presented lower $\mathrm{EC}_{50}$ values in reducing power assay and in the order $\quad$ Franquette $<$ Marbot $<$ Parisinne $<$ Mayette $<$ Mellanaise (Table 2).

DPPH assay has been widely used to determine the free radicalscavenging activity of various plants and pure compounds (Pereira et al., 2006; Ferreira et al., 2007; Sousa et al., 2008). DPPH is a stable free radical which dissolves in methanol, and its purple colour shows a characteristic absorption at $517 \mathrm{~nm}$. Antioxidant molecules scavenge the free radical by hydrogen donation, the colour from the DPPH assay solution becomes light yellow resulting in a decrease in absorbance at $517 \mathrm{~nm}$. Free radical scavenging is one of the known mechanisms by which antioxidants inhibit lipid oxidation (Ferreres et al., 2007). In this assay, results are expressed as the ratio percentage of the absorbance decrease of DPPH radical solution in the presence of extract at $517 \mathrm{~nm}$ to the absorbance of DPPH radical solution at the same wave length. In the present work, the scavenging effect on DPPH radicals assay also showed concentration-dependent activity (Fig. 3). For example to the aqueous extract of walnut husks $c v$. Franquette, at $0.01 \mathrm{mg} / \mathrm{mL}$, presented a scavenging effect of $3.81 \%$ that increase to $91.81 \%$ at $1 \mathrm{mg} / \mathrm{mL}$. All the studied extracts exhibited high scavenging properties against DPPH radicals, varying, at $1 \mathrm{mg} / \mathrm{mL}$ extract concentration, from $83.16 \%$ ( $c v$. Mellanaise) and 93.92\% ( $c v$. Marbot). The obtained results showed a strong antioxidant potential when comparing to the ones obtained for the standards (BHA: $96 \%$ at $3.6 \mathrm{mg} / \mathrm{mL}$ and $\alpha$-tocopherol: $95 \%$ at $8.6 \mathrm{mg} / \mathrm{mL}$ ). On DPPH assay, $\mathrm{EC}_{50}$ values obtained for aqueous walnut husks extracts varied between $0.35 \mathrm{mg} / \mathrm{mL}$ and $0.59 \mathrm{mg} / \mathrm{mL}$ in order of Franquette < Marbot $<$ Parisinne $=$ Mayette $<$ Mellanaise $($ Table 2). Samples with higher total phenols showed the strongest free radical-scavenging effect (lower $\mathrm{EC}_{50}$ values), being established a significantly negative linear correlation between the total phenols content and $\mathrm{EC}_{50}$ values (determination coefficients $0.795 ; p=0.042$ ).

In $\beta$-carotene linoleate model system free radical arisen from oxidation of linoleic acid, attacks the highly unsaturated $\beta$-carotene molecules, causing decrease of the absorbance at $470 \mathrm{~nm}$. The presence of different antioxidants can hinder the extent of $\beta$-carotene bleaching by neutralizing the linoleate-free radical and other free radicals formed in the system (Jayaprakasha et al., 2001). In the absence of antioxidants the absorbance at $470 \mathrm{~nm}$ 


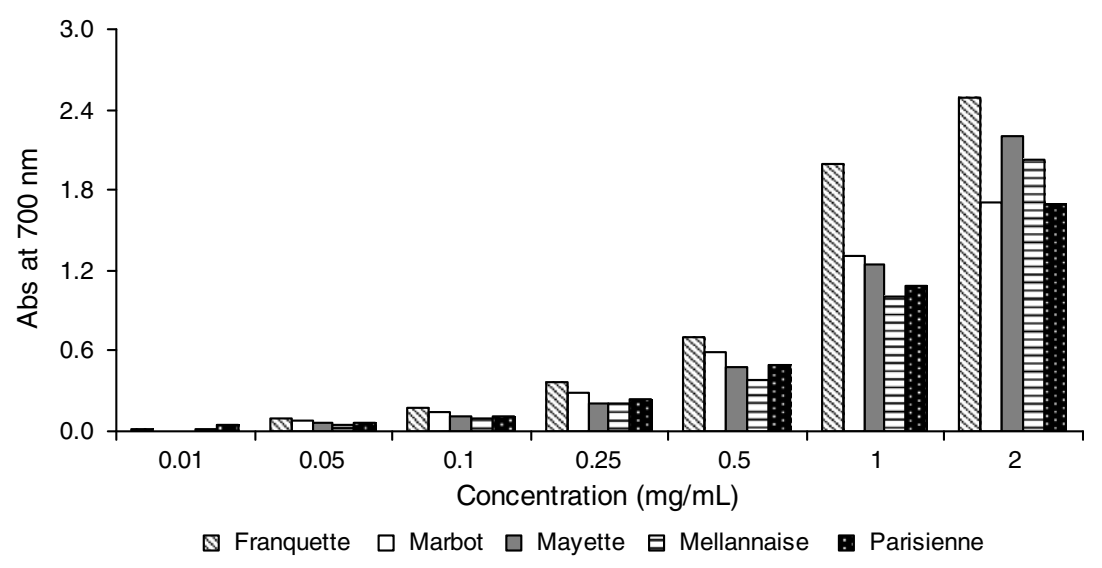

Fig. 2. Aqueous extracts reducing power values of walnut green husks from the Franquette, Mayette, Marbot, Mellanaise and Parisienne cultivars. Each value is expressed as mean \pm standard deviation.

Table 2

$\mathrm{EC}_{50}$ values $(\mathrm{mg} / \mathrm{mL})$ aqueous extracts of walnut green husks from the Franquette, Mayette, Marbot, Mellanaise and Parisienne cultivars

\begin{tabular}{llll}
\hline Cultivar & Reducing power $\left(\mathrm{EC}_{50}\right)$ & $\mathrm{DPPH}\left(\mathrm{EC}_{50}\right)$ & $\beta$-Carotene bleaching $\left(\mathrm{EC}_{25}\right)$ \\
\hline Franquette & 0.50 & 0.35 & 1.27 \\
Marbot & 0.51 & 0.42 & 0.60 \\
Mayette & 0.67 & 0.51 & 0.10 \\
Mellanaise & 0.70 & 0.59 & 1.17 \\
Parisienne & 0.62 & 0.51 & 0.92 \\
\hline
\end{tabular}

decreases rapidly, whereas in their presence, the colour, and thus absorbance, is retained for a longer time. The antioxidant activity of walnut green husks extracts, measured by the inhibition of $\beta$-carotene bleaching is shown in Fig. 4. The results showed a concentration-dependent antioxidant capacity and $\mathrm{EC}_{25}$ values varied from $0.1 \mathrm{mg} / \mathrm{mL}$ ( $c v$. Mayette) and $1.25 \mathrm{mg} / \mathrm{mL}$ ( $c v$. Franquette) (Table 2).

$c v$. Franquette proved to possess a much higher content of total phenols than all of the other cultivars. This occurrence can be related to the results obtained for the antioxidant assays, as $c v$. Franquette presents the higher values of total phenols and the better results for reducing power and scavenging activity on DPPH radicals assays, while $c v$. Mellanaise presents the worst results and the lower content of total phenols. In fact, several studies pointed out the antioxidant potential of phenols (Pereira et al., 2006; Ferreira et al., 2007; Ramadan and Moersel, 2006; Kornsteiner et al., 2006).

\subsection{Antimicrobial activity}

The study of antimicrobial capacity of plant phenolics is wellknown (Pereira et al., 2006; Pereira et al., 2007a,b; Proestos et al., 2005; Rauha et al., 2000). However, crude extracts tested by our group with other natural products (fruits and leaves) also showed good antimicrobial activities, such as tables olives (Pereira et al., 2006; Sousa et al., 2006), hazelnuts (Oliveira et al., 2007), walnuts (Pereira et al., in press), walnut leaves (Pereira et al., 2007b), olive leaves (Pereira et al., 2007a), hazelnut leaves (Oliveira et al., 2007) and different Brassica species flower buds (Sousa et al., in press). In this work, we propose the use of walnut green husks, a by-product of walnut production, as antimicrobials source. Borchers et al. (2004) reported that crude extracts may be more beneficial than isolated constituents, since a bioactive individual component can change its properties in the presence of other compounds present in the extracts.

The walnut green husks aqueous of different cultivars were screened for their antimicrobial properties against $B$. cereus, $B$. subtilis, S. aureus, E. coli, P. aeruginosa, K. pneumoniae, C. albicans and $C$. neoformans. The minimal inhibitory concentration (MIC) values for the tested bacteria and fungi were determined as an evaluation of the antimicrobial activity of the tested extracts. The halos of the inhibition zones corresponding to the MICs are also presented (Table 3 ). The response for each microorganism tested was different. All the tested extracts revealed antimicrobial activity showing different selectivity and MICs for each microorganism.

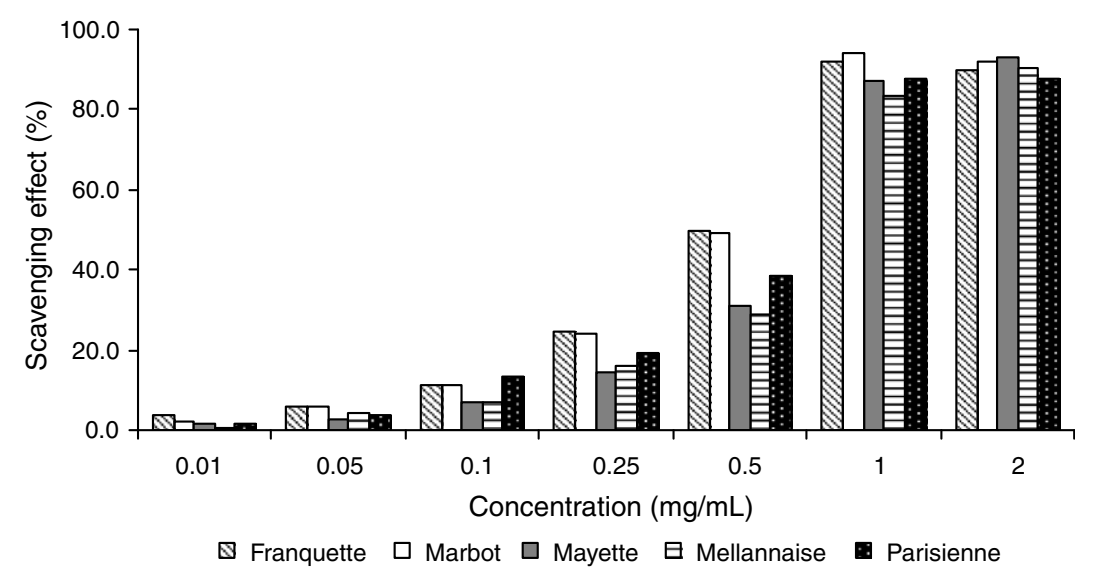

Fig. 3. Aqueous extracts scavenging effect on DPPH of walnut green husks from the Franquette, Mayette, Marbot, Mellanaise and Parisienne cultivars. Each value is expressed as mean \pm standard deviation. 


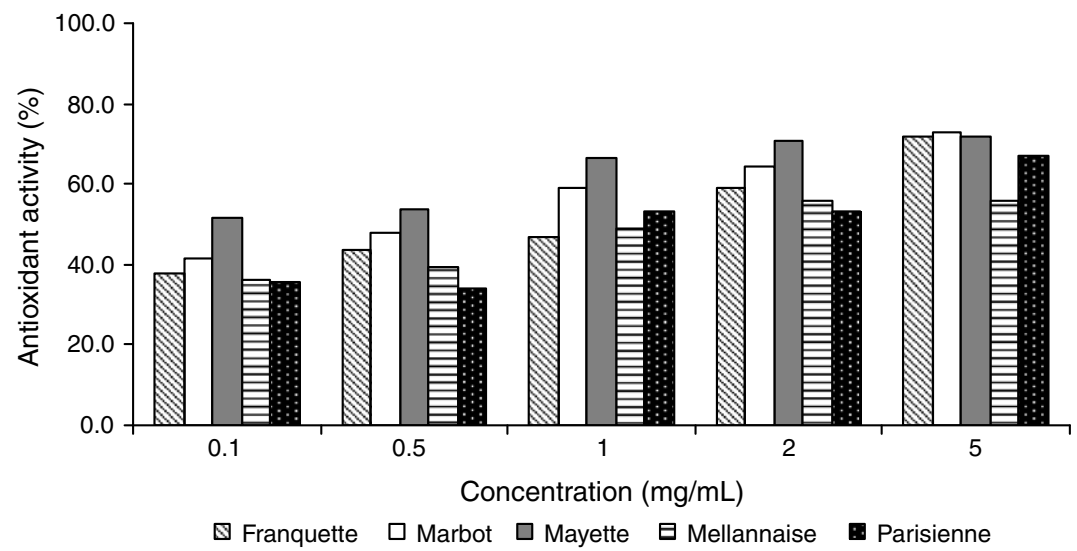

Fig. 4. Aqueous extracts antioxidant activity (\%) by $\beta$-carotene bleaching method of walnut green husks from the Franquette, Mayette, Marbot, Mellanaise and Parisienne cultivars. Each value is expressed as mean \pm standard deviation.

Table 3

Antimicrobial activity of aqueous extracts of walnut green husks from different cultivars

\begin{tabular}{|c|c|c|c|c|c|c|c|c|}
\hline \multirow[t]{2}{*}{ Cultivar } & \multicolumn{8}{|c|}{$\mathrm{MIC}(\mathrm{mg} / \mathrm{mL})$} \\
\hline & B. cereus & B. subtilis & S. aureus & P. aeruginosa & E. coli & K. pneumoniae & C. albicans & C. neoformans \\
\hline Franquette & $\begin{array}{l}0.1 \\
(++++)\end{array}$ & $\begin{array}{l}10 \\
(+++)\end{array}$ & $\begin{array}{l}0.1 \\
(++++)\end{array}$ & $\begin{array}{l}100 \\
(++)\end{array}$ & $\begin{array}{l}100 \\
(-)\end{array}$ & $\begin{array}{l}100 \\
(-)\end{array}$ & $\begin{array}{l}100 \\
(-)\end{array}$ & $\begin{array}{l}100 \\
(-)\end{array}$ \\
\hline Marbot & $\begin{array}{l}1 \\
(++++)\end{array}$ & $\begin{array}{l}0.1 \\
(+++)\end{array}$ & $\begin{array}{l}0.1 \\
(++++)\end{array}$ & $\begin{array}{l}100 \\
(+)\end{array}$ & $\begin{array}{l}100 \\
(-)\end{array}$ & $\begin{array}{l}100 \\
(-)\end{array}$ & $\begin{array}{l}100 \\
(-)\end{array}$ & $\begin{array}{l}100 \\
(-)\end{array}$ \\
\hline Mayette & $\begin{array}{l}0.1 \\
(++++)\end{array}$ & $\begin{array}{l}10 \\
(++)\end{array}$ & $\begin{array}{l}0.1 \\
(+++)\end{array}$ & $\begin{array}{l}100 \\
(-)\end{array}$ & $\begin{array}{l}100 \\
(-)\end{array}$ & $\begin{array}{l}100 \\
(-)\end{array}$ & $\begin{array}{l}100 \\
(-)\end{array}$ & $\begin{array}{l}100 \\
(-)\end{array}$ \\
\hline Mellanaise & $\begin{array}{l}0.1 \\
(++++)\end{array}$ & $\begin{array}{l}0.1 \\
(++++)\end{array}$ & $\begin{array}{l}0.1 \\
(++++)\end{array}$ & $\begin{array}{l}100 \\
(-)\end{array}$ & $\begin{array}{l}100 \\
(-)\end{array}$ & $\begin{array}{l}100 \\
(-)\end{array}$ & $\begin{array}{l}100 \\
(-)\end{array}$ & $\begin{array}{l}100 \\
(-)\end{array}$ \\
\hline Parisienne & $\begin{array}{l}0.1 \\
(++)\end{array}$ & $\begin{array}{l}0.1 \\
(++++)\end{array}$ & $\begin{array}{l}0.1 \\
(++++)\end{array}$ & $\begin{array}{l}100 \\
(-)\end{array}$ & $\begin{array}{l}100 \\
(-)\end{array}$ & $\begin{array}{l}100 \\
(-)\end{array}$ & $\begin{array}{l}100 \\
(-)\end{array}$ & $\begin{array}{l}100 \\
(-)\end{array}$ \\
\hline
\end{tabular}

No antimicrobial activity $(-)$, inhibition zone $<1 \mathrm{~mm}$. Slight antimicrobial activity $(+)$, inhibition zone $2-3$ mm. Moderate antimicrobial activity $(++)$, inhibition zone $4-$ $5 \mathrm{~mm}$. High antimicrobial activity $(+++)$, inhibition zone $6-9 \mathrm{~mm}$. Strong antimicrobial activity $(++++)$, inhibition zone $>9 \mathrm{~mm}$. Standard deviation $\pm 0.5 \mathrm{~mm}$.

Gram positive bacteria were the most sensitive being inhibited by all the extracts. Concerning Gram negative bacteria, only the extracts of $c v$. Franquette and $c v$. Marbot were able to inhibit the growth of $P$. aeruginosa at the highest extract concentration tested $(100 \mathrm{mg} / \mathrm{mL})$; fungi were resistant. The pure active compounds ampiciline and cycloheximide presented lower MICs than the walnut husk extracts.

The extracts presented similar antimicrobial capacity, inhibiting Gram + bacteria and in the order S. aureus $>$ B. cereus $>$ B. subtilis. S. aureus was the most susceptible microorganism, presenting MICs of $0.1 \mathrm{mg} / \mathrm{mL}$. These results are very important considering that $S$. aureus can produce several types of enterotoxins that cause gastroenteritis, which is a major food-borne disease in most countries (Halpin-Dohnalek and Marth, 1989). Natural products may be a particularly rich source of anti-infective agents. For example, flavonoids showed antimicrobial activity, and quercetin and other related compounds acts essentially by enzyme inhibition of DNA gyrase (Cushnie and Lamb, 2005).

The obtained results are similar, and in some cases better, than previous results obtained with different aqueous extracts of walnut leaves (Pereira et al., 2007b). The MICs were very similar but two of the tested extracts in this work showed inhibition of $P$. aeroginosa, which was not observed with leaves extracts. On the other hand, extracts of walnut fruits (Pereira et al., in press) were much less effectives.

In conclusion, the results obtained in our work showed that walnut green husks can be used as an easily accessible source of natural bioactive compounds. We demonstrate for the first time, as far we known, that walnut green husks aqueous extracts pre- sented a strong antioxidant activity and inhibited the growth of different pathogenic bacteria (Gram +) that can causes health problems. Further studies will be developed to characterize walnut green husks extracts and to identify the molecules responsible for this bioactivity. On other hand, the potential showed by walnut green husks extracts can lead to the valorization of a by-product, that nowadays has a scarce use.

\section{Conflict of interest statement}

The authors declare that there are no conflicts of interest.

\section{Acknowledgement}

The authors are grateful to INTERREG III A Program, Project PIREFI for financial support of this work.

\section{References}

Alkhawajah, A.M., 1997. Studies on the antimicrobial activity of Juglans regia. Am. J Chinese Med. 2008 (25), 175-180.

Almeida, I.F., Fernandes, E., Lima, J.L.F.C., Costa, P.C., Bahia, M.F., 2008. Walnut (Juglans regia) leaf extracts are strong scavenger of pro-oxidant reactive species. Food Chem. 106, 1014-1020.

Amaral, J.S., Seabra, R.M., Andrade, P.B., Valentão, P., Pereira, J.A., Ferreres, F., 2004 Phenolic profile in the quality control of walnut (Juglans regia L.) leaves. Food Chem. 88, 373-379.

Borchers, A.T., Keen, C.L., Gerstiwin, M.E., 2004. Mushrooms, tumors, and immunity: an update. Exp. Biol. Med. 229, 393-406. 
Clark, A.M., Jurgens, T.M., Hufford, C.D., 1990. Antimicrobial activity of juglone. Phytother. Res. 4, 11-14.

Cowan, M.M., 1999. Plant products as antimicrobial agents. Clin. Microbiol. Rev. 12, 564-582.

Cushnie, T.P.T., Lamb, A.J., 2005. Antimicrobial activity of flavanoids. Int. J. Antimicrob. Ag. 26, 343-356.

Espín, J.C., Soler-Rivas, C., Wichers, H.J., 2000. Characterization of the total free radical scavenger capacity of vegetable oils and oil fractions using 2,2-diphenyl1-picrylhydrazyl radical. J. Agric. Food Chem. 48, 648-656.

Fernández, M., Garcia, M., Sáenz, M., 1996. Antibacterial activity of the phenolic acid fraction of Scrophularia frutescens and Scrophularia sambucifolia. J. Ethnopharmacol. 53, 11-14.

Ferreira, I.C.F.R., Calhelha, R.C., Estevinho, L.M., Queiroz, M.-J.R.P., 2004. Screening of antimicrobial activity of diarylamines in the 2,3,5-trimethylbenzo[b]thiophene series: a structure-activity evaluation study. Bioorg. Med. Chem. Lett. 14, 58315833.

Ferreira, I.C.F.R., Barros, L., Soares, M.E., Bastos, M.L., Pereira, J.A., 2007. Antioxidant activity and total phenolic contents of Olea europaea L. leaves sprayed with different copper formulations. Food Chem. 103, 188-195.

Ferreres, F., Sousa, C., Valentão, P., Seabra, R.M., Pereira, J.A., Andrade, P.B., 2007. Tronchuda cabbage (Brassica oleracea L. var. costata DC) seeds: phytochemical characterization and antioxidant potential. Food Chem. 2007 (101), 549-558.

Halpin-Dohnalek, M.I., Marth, E.H., 1989. Staphylococcus aureus: production of extracellular products and behavior in foods: a review. J. Food Protect. 4, 267282.

Hatano, T., Kagawa, H., Yasuhara, T., Okuda, T., 1988. Two new flavonoids and other constituents in licorice root: their relative astringency and scavenging effects. Chem. Pharm. Bull. 36, 2090-2097.

Hoult, J., Payá, M., 1996. Pharmacological and biochemical actions of simple coumarins: natural products with therapeutic potential. Gen. Pharmacol. 27, 713-722.

Jayaprakasha, G.K., Singh, R.P., Sakariah, K.K., 2001. Antioxidant activity of grape seed (Vitis vinifera) extracts on peroxidation models in vitro. Food Chem. 73, 285-290.

Kornsteiner, M., Wagner, K.-H., Elmadfa, I., 2006. Tocopherol and total phenolics in 10 different nut types. Food Chem. 98, 381-387.

Li, L., Tsao, R., Yang, R., Liu, C.M., Zhu, H.H., Young, J.C., 2006. Polyphenolic profiles and antioxidant activities of heartnut (Juglans ailanthifolia var. cordiformis) and Persian walnut (Juglans regia L.). J. Agric. Food Chem. 54, 8033-8040.

Li, L., Tsao, R., Yang, R., Kramer, J.K.G., Hernandez, M., 2007. Fatty acid profiles, tocopheol contents, and antioxidant activities of heartnut (Juglans ailanthiofolia var. cordiformis) and Persian walnut (Juglans regia L.). J. Agric. Food Chem. 55, 1164-1169.

Mahoney, N., Molyneux, R.J., Campbell, B.C., 2000. Regulation of aflotoxin production by naphtoquinones of walnut (Juglans regia). J. Agric. Food Chem. $48,4418-4421$.

Meir, S., Kanner, J., Akiri, B., Philosoph-Hadas, S., 1995. Determination and involvement of aqueous reducing compounds in oxidative defense systems of various senescing leaves. J. Agric. Food Chem. 43, 1813-1819.

Mi-Yae, S., Tae-Hun, K., Nak-Ju, S., 2003. Antioxidants and free radical scavenging activity of Phellinus baumii (Phellinus of Hymenochaetaceae) extracts. Food Chem. 82, 593-597.

Oliveira, I., Sousa, A., Valentão, P., Andrade, P., Ferreira, I.C.F.R., Ferreres, F., Bento, A., Seabra, R., Estevinho, L., Pereira, J.A., 2007. Hazel (Corylus avellana L.) leaves as source of antimicrobial and antioxidative compounds. Food Chem. 105, 10181025.

Oyaizu, M., 1986. Studies on products of browning reactions: Antioxidative activities of products of browning reaction prepared from glucosamine. Jpn J. Nut. 44, 307-315.

Pereira, J.A., Pereira, A.P.G., Ferreira, I.C.F.R., Valentão, P., Andrade, P.B., Seabra, R., Estevinho, L., Bento, A., 2006. Table olives from Portugal: phenolic compounds, antioxidant potential and antimicrobial activity. J. Agric. Food Chem. 54, 84258431.

Pereira, A.P., Ferreira, I.C.F.R., Marcelino, F., Valentão, P., Andrade, F., Seabra, R., Estevinho, L., Bento, A., Pereira, J.A., 2007a. Phenolic compounds and antimicrobial activity of olive (Olea europaea L. CV. Cobrançosa) leaves. Molecules 12, 1153-1162.

Pereira, J.A, Oliveira, I. Sousa, A, Valentão, P., Andrade, P.B., Ferreira, I.C.F.R, Ferreres, F., Bento, A., Seabra, R., Estevinho, L., 2007b. Walnut (Juglans regia L.) leaves: phenolic compounds, antimicrobial activity and antioxidant potential of different cultivars. Food Chem. Toxicol. 45, 2287-2295.

Pereira, J.A. Oliveira, I., Sousa, A., Ferreira, I.C.F.R., Bento, A, Estevinho, L, 2008. Bioactive properties and chemical composition of six walnut (Juglans regia $\mathrm{L}$.) cultivars. Food Chem. Toxicol. 46, 2103-2111.

Proestos, C., Chorianopoulos, N., Nychas, G.-J.E., Komaitis, M., 2005. RP-HPLC analysis of the phenolic compounds of plant extracts. Investigation of their antioxidant capacity and antimicrobial activity. J. Agric. Food Chem. 53, 11901195.

Pulido, R., Bravo, L., Saura-Calixto, F., 2000. Antioxidant activity of dietary polyphenols as determined by a modified ferric reducing/antioxidant power assay. J. Agric. Food Chem. 2000 (48), 3396-3402.

Puupponen-Pimiä, R., Nohynek, L., Meier, C., Kähkönen, M., Heinonen, M., Hopia, A., Oksman-Caldentey, K.-M., 2001. Antimicrobial properties of phenolic compounds from berries. J. Appl. Microbiol. 90, 494-507.

Ramadan, M., Moersel, J., 2006. Screening of the antiradical action of vegetable oils. J. Food Compos. Anal. 19, 838-842.

Rauha, J.-P., Remes, S., Heinonen, M., Hopia, A., Kähkönen, M., Kujala, T., Pihlaja, K., Vuorela, H., Vuorela, P., 2000. Antimicrobial effects of Finnish plant extracts containing flavonoids and other phenolic compounds. Int. J. Food Mic. 56, 3-12.

Silva, B.M., Andrade, P.B., Valentãoo, P., Ferreres, F., Seabra, R.M., Ferreira, M.A., 2004. Quince (Cydonia oblonga Miller) fruit (pulp, peel, and seed) and jam: antioxidant activity. J. Agric. Food Chem. 52, 4705-4712.

Singleton, V.L., Rossi Jr., J.A., 1965. Colorimetric of total phenolics with phosphomolybdic-phosphotungstic acid reagents. Am. J. Enol. Viticult. 16, $144-158$.

Sousa, A., Ferreira, I.C.F.R., Calhelha, R., Andrade, P.B., Valentão, P., Seabra, R., Estevinho, L., Bento, A., Pereira, J.A., 2006. Phenolics and antimicrobial activity of traditional stoned table olives "alcaparra". Bioorg. Med. Chem. 14, 85338538 .

Sousa, A., Ferreira, I.C.F.R., Barros, L., Bento, A., Pereira, J.A., 2008. Antioxidant potential of traditional stoned table olives "Alcaparras": influence of the solvent and temperature extraction conditions. LWT - Food Sci. Technol. 41, 739-745.

Sousa, C., Taveira, M., Valentão, P., Fernandes, F., Pereira, J.A., Estevinho, L., Bento, A., Ferreres, F., Seabra, R.M., Andrade, P.B., in press. Inflorescences of Brassicacea species as source of bioactive compounds: A comparative study. Food Chem. doi:10.1016/j.foodchem.2008.02.087.

Stampar, F., Solar, A., Hudina, M., Veberic, R., Colaric, M., 2006. Traditional walnut liqueur - cocktail of phenolics. Food Chem. 95, 627-631.

Tseng, T.-H., Kao, E.-S., Chu, C.-Y., Chou, F.-P., Lin Wu, H.-W., Wang, C.-J., 1997. Protective effects of dried flower extracts of Hibiscus sabdariffa L. against oxidative stress in rat primary hepatocytes. Food Chem. Toxicol. 35, 1159-1164.

Valko, M., Leibfritz, D., Moncol, J., Cronin, M.T.D., Milan Mazur, M., Telser, J., 2007. Free radicals and antioxidants in normal physiological functions and human disease. Int. J. Biochem. Cell. Biol. 39, 44-84.

Zhu, X., Zhang, H., Lo, R., 2004. Phenolic compounds from the leaf extract of artichoke (Cynara scolymus L.) and their antimicrobial activities.. J. Agric. Food Chem. 52, 7272-7278.

Zupko, I., Hohmann, J., Redei, D., Falkay, G., Janicsak, G., Mathe, I., 2001. Antioxidant activity of leaves of Salvia species in enzyme-dependent and enzymeindependent systems of lipid peroxidation and their phenolic constituents. Planta Med. 67, 366-368. 